\title{
Safety performance functions in Dedicated Bus Lane of BRT on Caracas Avenue Corridor at Bogotá city
}

\section{Funciones de desempeño de seguridad en carriles de uso exclusivos del BRT sobre el corredor de la Avenida Caracas en la ciudad de Bogotá}

\author{
DOI: http://dx.doi.org/10.17981/ingecuc.15.2.2019.07
}

Artículo de Investigación Científica. Fecha de Recepción: 11/02/2019. Fecha de Aceptación: 14/08/2019.

\author{
Kelly Andrea Rodríguez-Polo \\ Escuela Colombiana de Ingeniería Julio Garavito. Bogotá (Colombia) \\ kelly.rodriguez-p@mail.escuelaing.edu.co \\ Santiago Henao-Pérez \\ Escuela Colombiana de Ingeniería Julio Garavito. Bogotá (Colombia) \\ santiago.henao@escuelaing.edu.co
}

Para citar este artículo:

K. Rodríguez-Polo and S. Henao-Pérez., "Safety performance functions in Dedicated Bus Lane of BRT on Caracas Avenue Corridor at Bogotá city”, INGE CUC, vol. 15, no. 2, pp. 66-77, 2019. DOI: http://doi.org/10.17981/ingecuc.15.2.2019.07

\begin{abstract}
Introduction- Road safety is a global concern due to the temporary and/or permanent health effects that traffic accidents generate for the people involved. On the other hand, Bus Rapid Transit (BRT) systems a large number of passengers and during their operation they become involved in this type of problem.

Objective- Accident prediction model implemented in the Highway Safety Manual 2010 or HSM is an alternative to evaluate the strategies that allow to reduce accidents in this type of systems. However, there is not specified Safety Performance Functions (SPFs) developed for BRT systems. In the present work, the accident model of HSM is adapted by calibration of general SPFs expressions of the manual and also, SPFs were developed for BRTs installed on the central-line of main roads and use an exclusive lane of all other transport systems (both public or private) and mobility (e.g. bike paths).
\end{abstract}

Methodology / Results- Crashes reports and traffic volumes data supplied by the Department of Transportation of Bogotá (Colombia) were used. The model was calibrated using the safety performance functions (SPFs) of the HSM and a specific developed functions for the BRT conditions. These SPFs were developed using a negative binomial model in roadway segments and intersections.

Conclusions- Through the validation, it was determined that the developed functions have a better fit than the SPFs established in the HSM. These developed SPFs can be used as a tool to define safety performance guidelines of Bogotá's BRT corridors in the coming years.

Keywords- Bus Rapid transit; Highway Safety Manual; Safety Performance Functions; Urban and Suburban Arterials; Crash Modification Factors; Negative Binomial Regression Model; Roadway Segments; Intersections; Accidents Estimation Model

\section{Resumen}

Introducción- La seguridad vial es una preocupación global debido a las afectaciones en la salud de carácter temporal y/o permanente que los accidentes de tránsito generan para las personas involucradas. Por otro lado, los Sistemas de Buses de Tránsito Rápido (BRT) transportan una gran cantidad de pasajeros y durante su operación se involucran en este tipo de problema.

Objetivo- El modelo de estimación de accidentes del Manual de Seguridad Vial de los Estados Unidos (HSM-2010) es una alternativa para evaluar las estrategias de reducción de accidentes en este tipo de sistemas. Sin embargo, no hay Funciones de Desempeño de Seguridad (SPFs) Vial desarrolladas para los BRT. Por tanto, en este estudio se calibra el modelo de accidentes del HSM usando las expresiones generales de SPFs del manual, además de proponer SPFs para el sistema BRT que operen sobre las avenidas usando un carril de uso exclusivo ubicado en el centro de la vía, separado de todos los demás sistemas de transporte (público o privado) y movilidad (por ejemplo ciclo-vías).

Metodología / Resultados-Se utilizaron los reportes de accidentalidad y los volúmenes de tráfico suministrados por la Secretaria de Movilidad de Bogotá. El modelo se calibró utilizando las funciones de desempeño de seguridad del HSM, desarrollando funciones para las condiciones específicas del BRT y empleando un modelo binomial negativo, tanto para segmentos de vía como intersecciones. Conclusiones- Mediante el proceso de validación se determinó como las funciones desarrolladas tienen un mejor ajuste que las SPFs establecidas en el HSM. Estas SPFs desarrollados pueden emplearse para definir las pautas del desempeño de seguridad de los corredores del BRT en la ciudad de Bogotá durante los próximos años.

Palabras clave- Buses de Transito Rápido; Manual de Seguridad Vial; Funciones de Desempeño de la Seguridad; Avenidas Urbanas y Suburbanas; Factores de Modificación de Accidentes; Modelo de Regresión Binomial Negativo; Segmentos de Vía; Intersecciones; Modelo de Estimación de Accidentes. 


\section{INTRODUCTION}

Injuries due to traffic accidents represent a public health problem. In developed countries, these are the leading cause of death and the second burden of disease [1] [2] [3] [4]. The three main factors related to accidents are the driver, the road and the vehicle, where the road generates $34 \%$ of accidents [5]. Many countries adopt the reduction of traffic accidents as their main objective and it can be achieved through road safety studies [6]. Road safety is an emerging area that seeks to study the factors that involve traffic accidents and propose measures to mitigate this problem.

On the other hand, the increase in the density of urban occupation generates changes in modes of transport, migrating from private vehicle to public services, and other means such as bicycles. This makes it necessary to conduct road safety investigations on a regular bases [7]. In addition, to solve the demand for transport in urban areas, a large number of cities are beginning to consider the Bus Rapid Transit (BRT) as a sustainable alternative to meet the needs of massive transport [8]. However, it is important to consider that the BRT and Bus with High Level of Service (BHLS) is in a development stage, and therefore, the coordinated work towards its consolidation is necessary.

The benefits in the road safety of bus systems with exclusive lanes for BRT have been summarized in several recent works [9] [10]. However, the literature review has not found a specific methodology to assess the safety of this mode of transport. In terms of progress in this area, in 2005, Bogotá published a Road Safety Audits Manual with the objetive of defining strategies to contribute to the reduction of accident rates in the city considering all transportation modes [11]. However, only the first 5 years of Transmilenio's experience was considered and it does not involve accident prediction models. Although some changes have been implemented in the corridors, there is no a clear evidence that this type of change results in an improvement in safety [9].

As alternative, to evaluate the safety of urban transportation systems infrastructure is to apply the methodology established in the HSM. This methodology uses developed SPFs functions with crashes data reported in US to estimate the accidents on different scenarios. Nevertheless, the development of these functions is recommended according to its local conditions [5] [12] also, studies in which SPFs are developed and transferred to other localities are uncommon [13].

Several studies have been published recently developed SPFs of rural divided multilane highway segment on seven states of USA [13]. For every state, Negative Binomial (NB), zero-inflated NB, Poisson lognormal (PLN), regression tree, random forest (RF), boosting, Tobit models and a hybrid model Tobit-NB are used.
Results showed that the Tobit, RF, tree, NB and hybrid models demonstrate better predictive performances.

Aggregate models of collision expectations at stopcontrolled and signalized intersections in the same country they found that the Highway Safety Manual (HSM [5]) predictive equations are not a good representation of the average intersection collision expectation [14]. Also reported that, the current HSM models under-predict collisions at signalized urban intersections by a factor of about 2.0 and over-predict collisions at stop-controlled by factors of 1.1 .

In 2013, HSM recalibrated the previous calibration at the Missouri (USA) transportation facilities [15]. When comparing results, these depicted that for urban four-lane freeway segments, the multi-vehicle crashes with property damage only, the calibration factor has decreased from 3.59 to 1.46 due to the avoidance of the vicinity of interchanges, also, for urban signalized intersections, the three-leg and four-leg calibration values continue to be high (2.95 and 5.21).

In Kansas (USA) it was estimated calibration factors for SPFs [5] functions and developed SPFs for different types of urban intersection in Kansas [16]. The calibration factors for these facility types were estimated to be 0.64 for signalized three-leg (3SG) intersections, 0.51 for Three-Leg Stop-controlled (3ST) intersections, 1.17 for signalized four-leg (4SG) intersections, and 0.61 for Four-Leg Stop-controlled (4ST) intersections when considering crashes of all severities. As is expected, results showed that developed functions had more accuracy in crash prediction than calibration factors.

In this article, the methodology established [5] for urban and suburban arterials is adapted to estimate a model of the average crash frequency in dedicated bus lane of BRT at Bogotá. For this, a description of the Transmilenio transportation system and the assessment of different types of accidents are presented. Second, the HSM predictive method for urban and suburban arterials is illustrated, the calibration process of the SPFs [5] and the development of specify safety performance functions for the base conditions of the Caracas avenue corridor. Finally, conclusions and recommendations of the investigation are summarized.

\section{TRANSMILENIO DESCRIPCION AND BRT ACCIDENT DATA}

BRT systems are beginning to become an option to meet the needs of urban mobility in large cities. The Bogota's BRT system (Transmilenio) is integrated by $114.4 \mathrm{Km}$ of roads corresponding to 11 corridors in service, 9 end stations with garage, 139 stations, 41 guaranteed garages, 7454 bus stops, 13 operation zones, 3758 cycle -parking, 4315 charging points and 


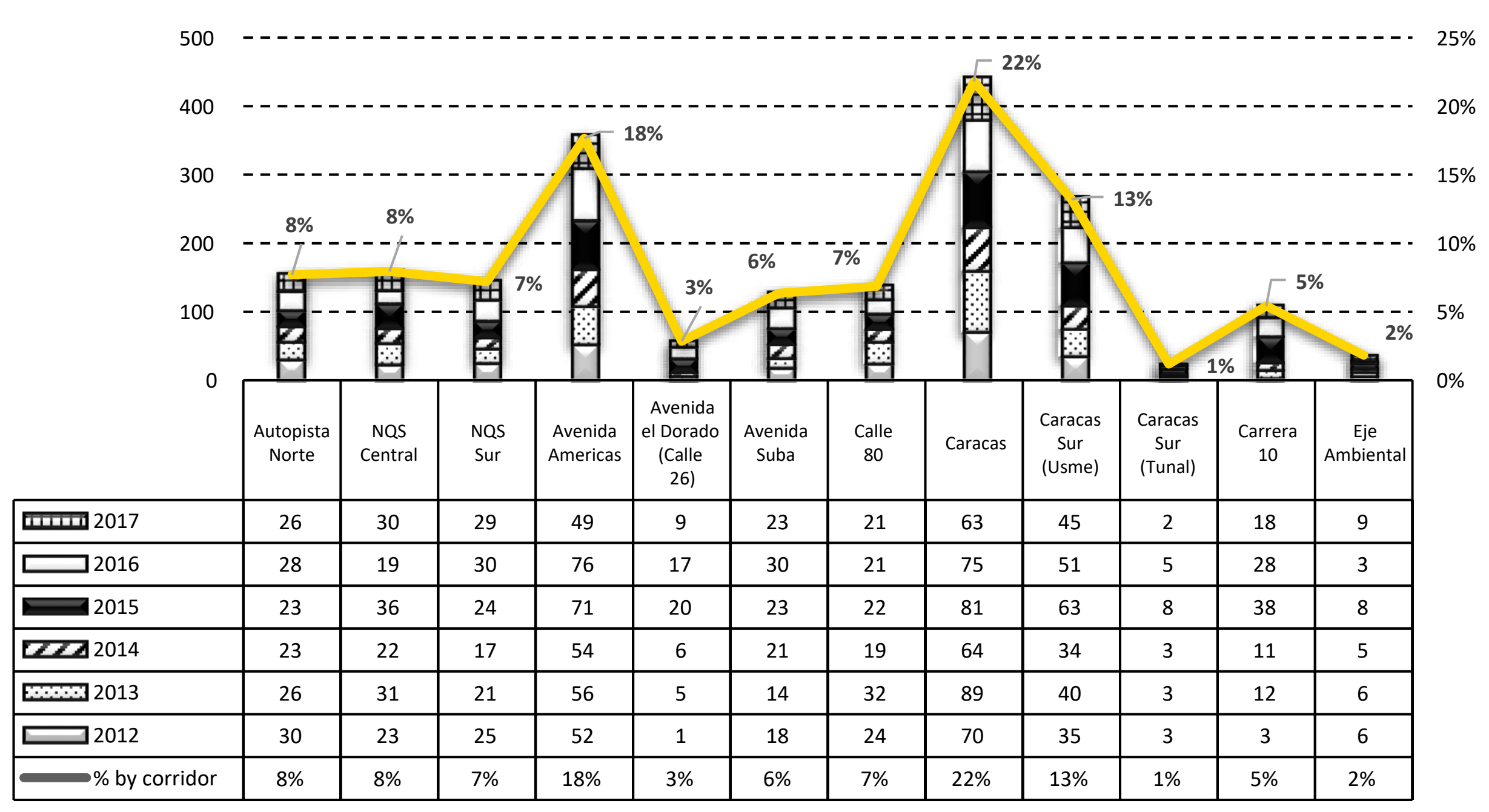

Fig 1. Total crash between 2012 to 2017 by TransMilenio corridors.

a single collection operator, with a centralized control center [17]. The passenger demand reported for 2015 was 2.213.236 passengers per day.

The crash data related to the BRT were obtained from the Secretary of Mobility of Bogotá corresponding to the years 2012 to 2016 with the following information: Accidents by time of occurrence (year and month), by severity (fatal and non-fatal), vehicle involved in collision with BRT (light, motorcycles, buses, trucks and bicycles), type of victims, age and gender (driver, passenger, pedestrian and cyclist) and location. These characteristics of the crash has been considered in recent road safety studies of the BRT [18], [19], [20]. From this information, an accident analysis was performed by time of occurrence (year and month), corridor, severity, vehicles involved in collision, class (vehicle-pedestrian collisions, vehicle collision, occupant fall and other), by victim (passenger, pedestrian, cyclist and driver) and ages. Fig. 1 shows the total accidents per corridor and it is depicted that the corridor with the highest accident rate is Caracas Avenue (Bogotá, Colombia).

Crashes were classified by location to perform the analysis [21]. The place can be a roadway segments or intersection, the address (nomenclature) and the class of accident reported (vehicle-pedestrian collisions, vehicle collision, occupant fall or other). When debugging and organizing the data was made a new reclassification of the accident site, following the next criteria:

- If the accident takes place at the corner of an intersection but there is a station in the same locations, the accident is related to the stop station and therefore, it is associated with the corresponding roadway segments where the station is located.

- All vehicle-pedestrian collisions that are located at the corner of an intersection are associated with accidents at the intersection.

- Occupant fall are associated witn the respective sections unless reported at the intersection.

- Crashes reported with an address where an intersection is located are associated with accidents at the intersection.

- "Other" like accidents, no modification of the place was done.

Accidents are also categorized into multiple-vehicles collision, single-vehicle collision and totals (not including those involving pedestrians and / or cyclists). The geometry of the road (e.g. lane width, number of lanes, width of the separator, etc.). Traffic volumes were provided by the Secretary of Mobility of Bogotá for several years and were projected considering the growth of the automotive fleet. Fig. 2 presents the location of the accidents at the most crashes corridors, which are "Caracas Avenue" (cyan marks), "Américas Avenue" (green marks) and "Caracas SurUsme" (purple marks). 


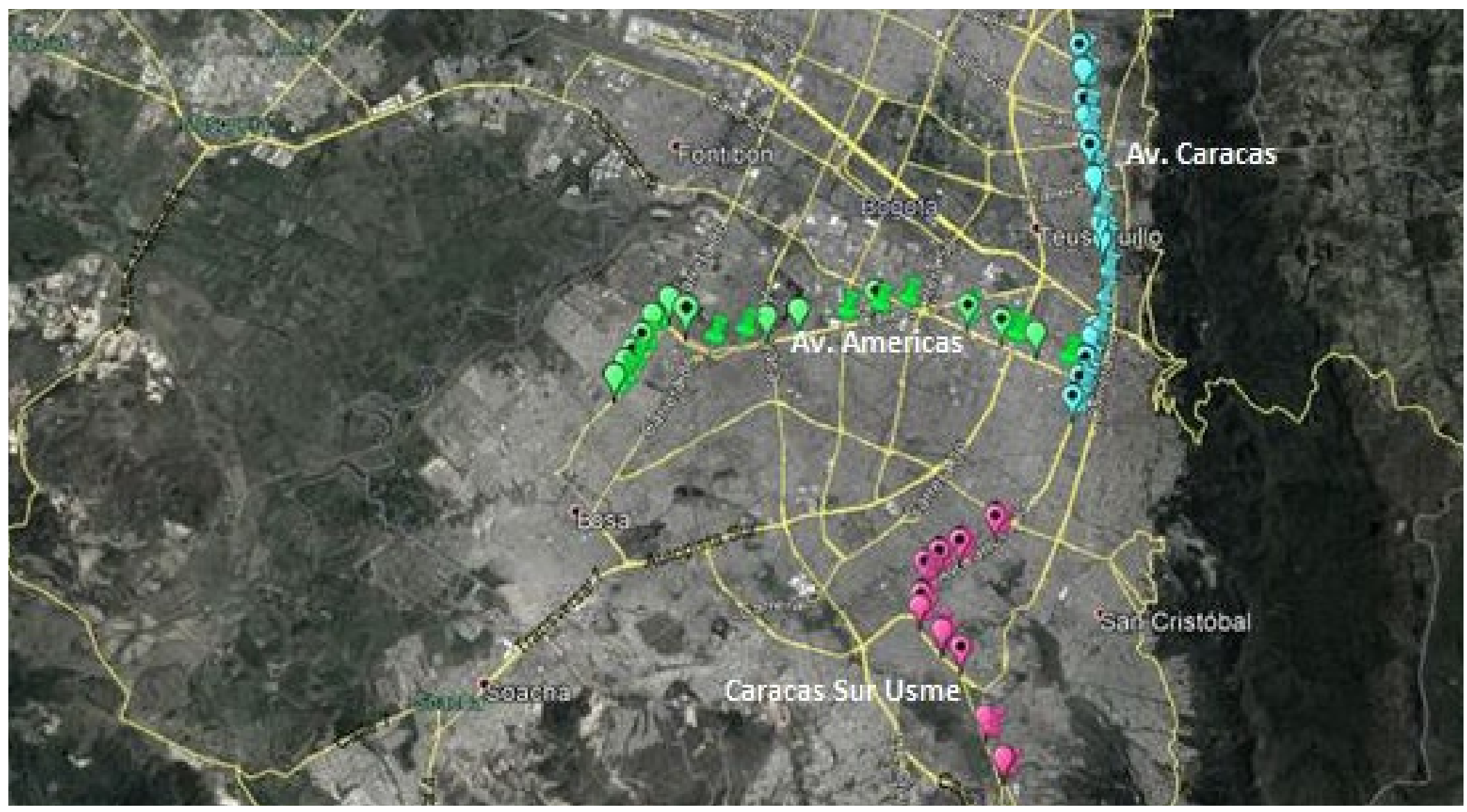

Fig. 2. Location of accidents at the most crashes corridors of Transmilenio on @GoogleEarth image. Source: Authors.

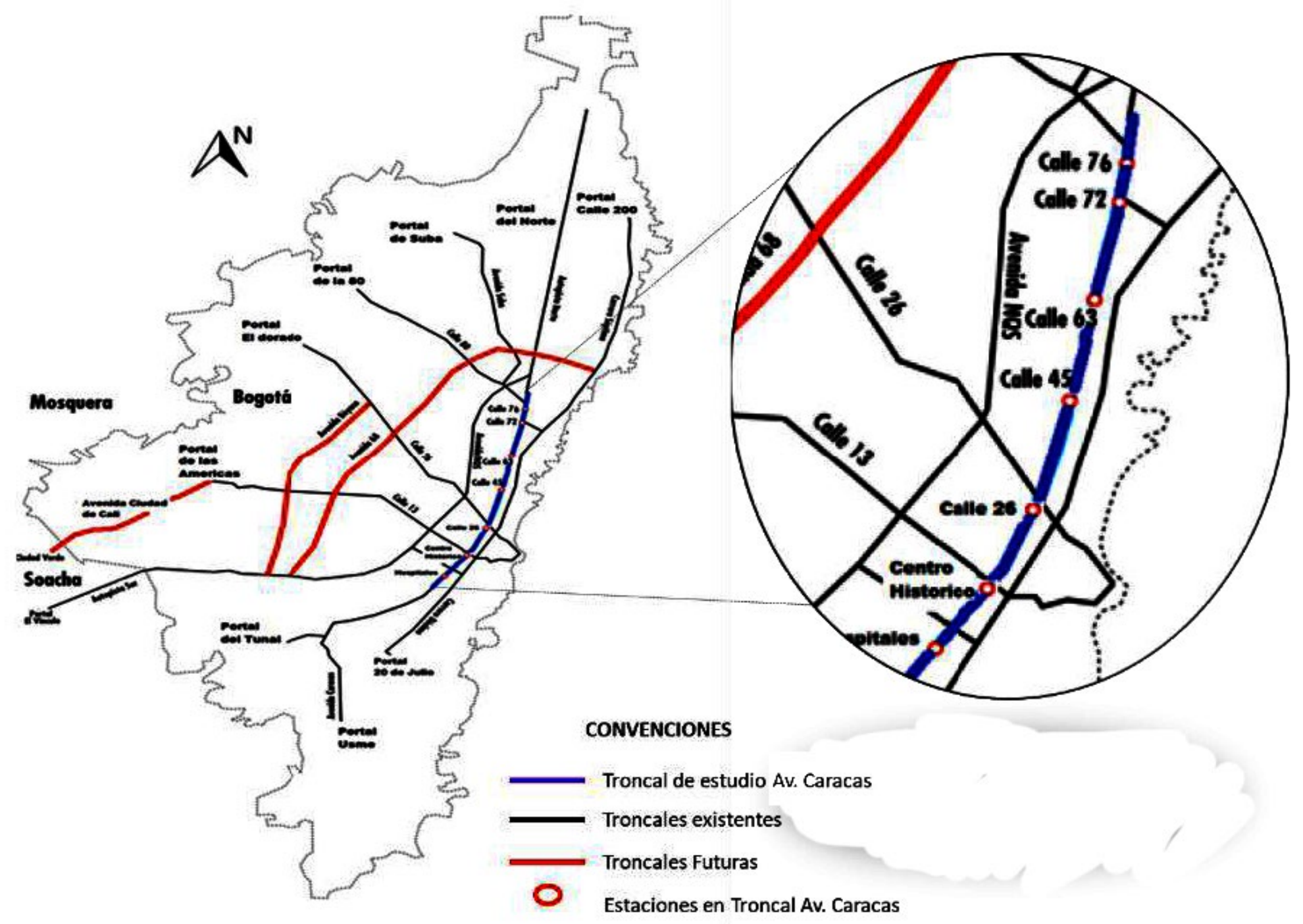

Fig. 3. Location map of the Caracas Avenue Corridor. Source: [24]

Due to the number of accidents in Caracas Avenue, this study is develop in part of its extension (6th street to 76th street) and in several sections of the "Caracas- Sur-Usme" corridor (11th street to 6th street). The road segments were selected taking into account the presence of pedestrian or vehicular intersections and a minimum length of $160 \mathrm{~m}$ (0.1 miles
[22]). As a result, the lengths of the segments are between $160 \mathrm{~m}$ and $542 \mathrm{~m}$ (Fig. 3, blue thick line). The maximum speed allowed in these corridors is 60 $\mathrm{km} / \mathrm{h}$ [23]. Therefore, the road sections have an intermediate or high speed (above $48 \mathrm{~km} / \mathrm{h}$ ) and are also classified as urban (i. e. surrounded by more than 5000 habitants) [5]. 


\section{INTRODUCTION PREDICTIVE METHOD FOR URBAN AND SUBURBAN ARTERIALS}

The HSM proposes a methodology to predict the safety of a specific road infrastructure by combining the use of historical accident data, analysis of accident regression models, "before-after" studies and opinions of experts on the subject [25]. The prediction process can be defined as follows [5]:

1. Select the roadway segment or intersection to be evaluated.

2. Apply a base preliminary model, which will generally be a negative binomial distribution. These functions are called in the HSM as Safety Performance Functions (SPFs).

3. On the Base Model, apply a calibration factor to adapt it to local conditions.

4. Adjust the calibrated model by means of Crash Modification Factors (CMFs) that represent the effects on the safety of a specific geometric design element and/or traffic control features of the evaluated element.

5. Estimate the frequency of accidents and their distribution by severity and type of collision.

6. Calculate the final values of the prediction.

The process to estimate accidents is determined by the following equation [5]:

$$
\begin{aligned}
\boldsymbol{N}_{\text {predic }}= & \left(N _ { S p f x } * \left(C M F_{1 x} * C M F_{2 x} * \ldots *\right.\right. \\
& \left.\left.C M F_{y x}\right)+N_{\text {peat } x}+N_{\text {bici }}\right) * C_{x}
\end{aligned}
$$

Where,

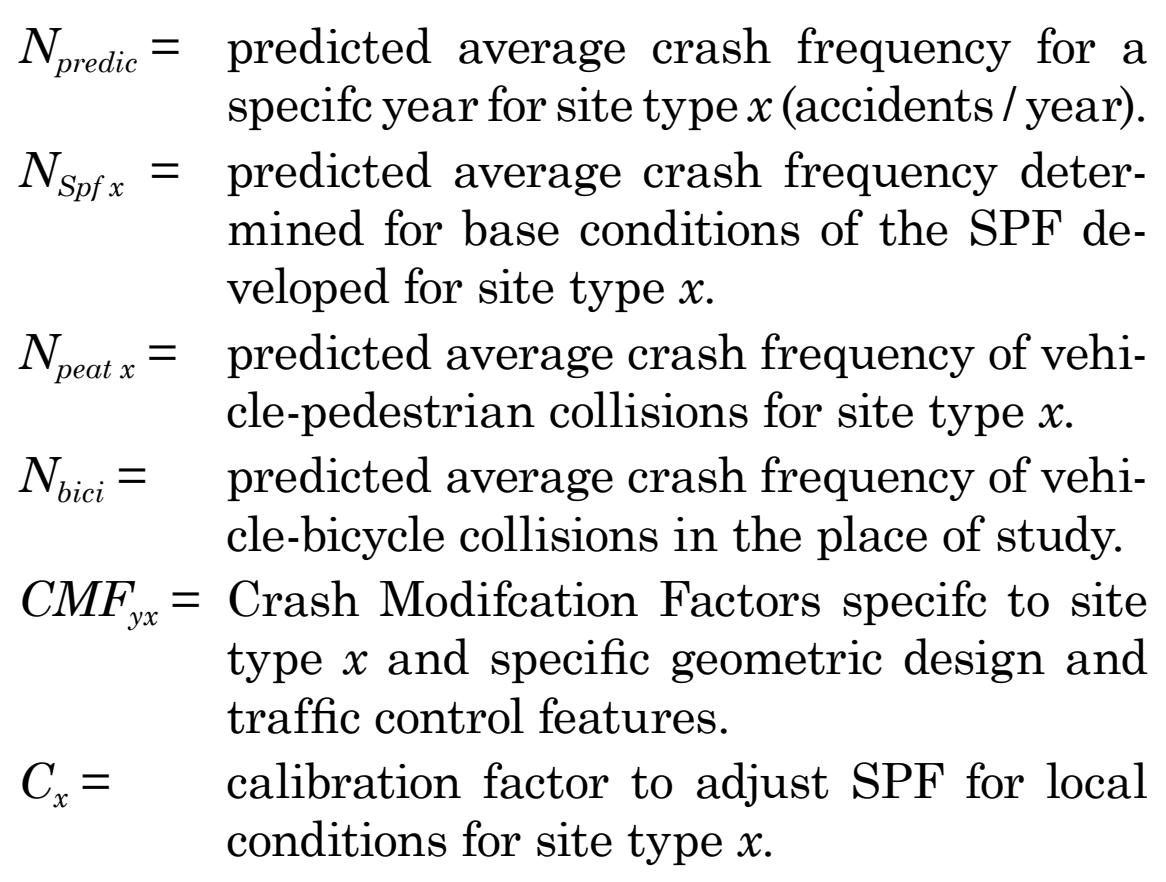

HSM provides models to estimate accident by severity and collision-type distributions for roadway segments and intersections. The SPFs are developed for each severity scale and accident type, primarily from accident data United States [5]. This paper is focused on the SPF models (Nspf) that are the bases of the HSM methodology.
IV. Development of the SAFETy PERFormance FUnCtions FOR BASES CONDITIONS OF AVENUE CARACAS CORRIDOR

For the application of the HSM guidelines it is necessary to classify the facility type according to the categories established [5]. In the case of the studied corridor of BRT system, it has roadway segments of Four-lane divided arterials called "4D" (including a raised or depressed median) and two types of intersection (3SG and 4SG).

The safety performance functions [5] have been formulated using information from the United States,

\begin{tabular}{|c|c|c|}
\hline Condition & $\begin{array}{l}\text { Exclusive } \\
\text { BRT lanes }\end{array}$ & HSM \\
\hline \multicolumn{3}{|c|}{ Roadway segments (worksheet 1a Chapter 12-HSM) } \\
\hline Lane width & $3.60 \mathrm{~m}(12 \mathrm{ft})$ & $3.60 \mathrm{~m} \mathrm{(12 \textrm {ft } )}$ \\
\hline Presence/type of on-street parking & Absence & Absence \\
\hline Median width & $4.12 \mathrm{~m}(13.5 \mathrm{ft})$ & $4.60 \mathrm{~m}(15 \mathrm{ft})$ \\
\hline Roadway lighting & Presence & Absence \\
\hline Speed control (Camera o Tableros) & Any & Any \\
\hline $\begin{array}{l}\text { Roadside fixed object density } \\
\text { (fixed objects/mi) }\end{array}$ & Absence* & Absence \\
\hline Offset to roadside fixed objects (ft) & Absence* $^{*}$ & Absence \\
\hline \multicolumn{3}{|c|}{ Intersections (worksheet $2 \mathrm{a}$ Chapter $12-\mathrm{HSM}$ ) } \\
\hline Intersection lighting & Presence & Absence \\
\hline $\begin{array}{l}\text { Number of major-road approaches } \\
\text { with left-turn signal phasing }\end{array}$ & 0 & 0 \\
\hline $\begin{array}{l}\text { Number of approaches with } \\
\text { intersection right turn lane }\end{array}$ & 0 & 0 \\
\hline $\begin{array}{l}\text { Number of approaches with right- } \\
\text { turn-on-red operation prohibited }\end{array}$ & 0 & 0 \\
\hline Type of left-turn signal phasing & Protected & Permissive \\
\hline Red Light Camera & Absence & Absence \\
\hline $\begin{array}{c}\text { Number of bus stops within } 300 \\
\text { meters (1000 feet) of the intersection }\end{array}$ & 1 to 2 & 0 \\
\hline $\begin{array}{l}\text { Presence of schools within } 300 \text { meters } \\
\text { (1000 feet) of the intersection }\end{array}$ & Presence & Absence \\
\hline $\begin{array}{l}\text { Number of alcohol sales } \\
\text { establishments within } 300 \text { meters } \\
\text { (1000) feet of the intersection }\end{array}$ & 1 to 8 & 0 \\
\hline
\end{tabular}
therefore, it is necessary to study the effectiveness of their use for the particular case of Bogota's BRT and proposes some expression that can better describe the observed crashes data (as has been reported by other researchers [14]). This section presents several considerations on which the accident estimation is done.

\section{A. Base conditions of the corridor}

A comparison of the base conditions identified for the BRT corridors and those presented [5] for the roadway segments and intersections is presented in Table 1. These is shown that there are differences in the median width and the presence of lighting for the case of the Transmilenio's exclusive lanes.

TABle 1. Comparison of the Base CONDitions of THE TransMilenio vs HSM.

* These data were not collected on the corridors studied since there are no single damage accidents with only one vehicle involved in the study sites. Source: Author. 


\section{B. Crash Modification Factors}

To compare the SPFs developed for the BRT lanes with the SPFs established [5], it is necessary to use the Crash Modification Factors (CMFs). Table 2 summarizes the factors that were applied to the model presented [5] to obtain equivalent results with the SPFs developed specifically for Bogotá city. Due to the configuration of the Bogota's BRT, within $300 \mathrm{~m}$ of radius near the intersections, there was at least 1 bus stop (Transmilenio station).

Table 2. Crash Modification factors used FOR THE BOGOTA's BRT

\begin{tabular}{|c|c|}
\hline \multicolumn{2}{|c|}{ For SPFs estimated using crashes data of BRT } \\
\hline Condition & CMF value \\
\hline $\begin{array}{l}\text { Number of Approaches with } \\
\text { Left-Turn Lanes (Table 12-24) }\end{array}$ & $\begin{array}{l}0.90,0.81,0.73 \text { y } 0.66 \text { for one } \\
\text { to four Approaches respectively }\end{array}$ \\
\hline $\begin{array}{l}\text { Number of Approaches with } \\
\text { Right-Turn Lanes (Table 12-26) }\end{array}$ & $\begin{array}{l}0.96,0.92,0.88 \text { y } 0.85 \text { for one } \\
\text { to four Approaches respectively }\end{array}$ \\
\hline $\begin{array}{l}\text { Number of Approaches with } \\
\text { Right-Turn-on-red prohibited } \\
\text { (Equation 12-35) }\end{array}$ & $0.98^{\wedge}$ (Number of Approaches) \\
\hline \multicolumn{2}{|c|}{ For SPFs established in the HSM } \\
\hline Median Width (Table 12-22) & 1.05 \\
\hline $\begin{array}{l}\text { Lighting at roadway segments } \\
\text { (Equation 12-34) }\end{array}$ & 0.91 \\
\hline $\begin{array}{l}\text { Lighting at intersections } \\
\text { (Equation 12-36) }\end{array}$ & 0.91 \\
\hline $\begin{array}{l}\text { Type of Left-Turn Signal Phasing } \\
\text { (Table 12-25) }\end{array}$ & 0.94 \\
\hline $\begin{array}{l}\text { Number of bus stops within } \\
300 \text { meters (1000 feet) of the } \\
\text { intersection (Table 12-28) }\end{array}$ & 2.78 \\
\hline $\begin{array}{l}\text { Presence of schools within } \\
300 \text { meters (1000 feet) of the } \\
\text { intersection (Table 12-29) }\end{array}$ & 1.35 \\
\hline $\begin{array}{c}\text { Number of alcohol sales } \\
\text { establishments within } 300 \text { meters } \\
\text { (1000) feet of the intersection. } \\
\text { (Table 12-30) }\end{array}$ & 1.12 \\
\hline
\end{tabular}

Source: Authors from [5].

Also, in most of the intersections there is a presence of schools and alcohol sales establishments within $300 \mathrm{~m}$ due to the mixed use of land at the Caracas corridor. The presence of a red light camera was not identified in the study area and only one speed camera was identified in one case (intersection at 6th street).

\section{Participation of different actors according to local conditions}

Using the methodology established in appendix A.1.3 [5], the pedestrian crash adjustment factor was updated (fpedr) for intersections by means of the expression:

$$
f_{p d r}=\frac{K_{p e d}}{K_{n o n}}
$$

Where $K_{\text {ped }}$ is the observed vehicle-pedestrian crash frequency and $K_{n o n}$ the observed frequency for all crashes not including vehicle-pedestrian and vehiclebicycle crash. The bicycle crash adjustment factor was not estimated since only a total of 3 and 6 accidents were reported for roadway segments and intersections correspondingly. Considering 42 and 29 vehicle-pedestrian collisions occurred during the study period at $3 \mathrm{SG}$ and $4 \mathrm{SG}$ intersections respectively, a value of $f_{\text {pedr }}$ $=0.457$ and 0.315 for intersections were determined. These accident adjustment factors are almost $50 \%$, thereby, it is important to work on the implementation of measures that reduce these rates. Additionally, when comparing the pedestrian crash adjustment factors with those reported at intersection in urban arteries [5] (0.019 and 0.022 for 3SG and 4SG intersections respectively), it is necessary to calibrate these values to obtain reliable predictions that allow the implementation of goals regarding the operation safety of the Bogota BRT.

The contribution of accidents that do not involve pedestrians and / or bicycles is $13 \%$ involve multiplevehicles $(7.9 \%$ with injuries and / or fatal and $4.7 \%$ with property damage only) and $50 \%$ involve a singlevehicle $(48.8 \%$ with injuries and / or fatal and $1.6 \%$ with property damage only). It is important to note that the high number of accidents involving a singlevehicle is associated with the occupants fall during the articulated-vehicle arrives at or leaves from a station.

\section{Estimating Models of SPFs}

Although some SPFs are presented [5], the development of these functions is recommended in the manual according to its local conditions. Using goodness-of-fit measures and four years of accident data (2007-2010) from the state of Florida, safety performance functions (SPFs) were developed in segments of roads for urban and rural areas [26], using a negative binomial (NB) regression model. The results of the goodnessof-fit showed that the SPF developed presented a better fit than the model calibrated using the SPFs [5]. Other research calibrates the SPFs [5] and develops new models for two-lane rural roads in each direction in the state of Utah using 3 years of crashes reports [27] determining as significant variables the average annual daily traffic volume (AADT), segment length, speed limit and percentage of ADDT made up of trucks.

The most common models for the development of SPFs are Poisson and NB [26]. Regressions with a Poisson distribution have been used to model the relationship between accident types and independent variables such as section geometry and time of day [28] and, to model the relationship between the types of accident, severity, traffic volumes among others [29]. 
However, the parameters estimated by this regression model can introduce bias and inconsistencies because the variance is restricted to the median and, the variance in the number of accidents usually exceeds the average [26]. Due to the dispersion presented in this study, it is evident in most cases that the variance exceeds the mean (Table 4 and Table 8), the NB model is used in this research to develop the Transmilenio's specific SPFs. Nowadays, the usual one model for predicting crash counts is the NB model [13].

In the case of roadway segments, the most frequent accident reported in the database for a single-vehicle collision occurs due to the occupant's fall that usually take place in the sections where there is a BRT station (39 accidents). Consequently, the analysis of the SPFs is presented for both roadway segments, i.e. with or without bus-stop stations to identify the differences in that cases and the relationship of crashes and the presence of the station.

The form of the function used to describe the number of accidents is in general, the form of the SPF model used in the safety analyzes [26], i.e. an exponential model that is a linear combination of the effect of variables considered (Table 5 and Table 9). To choose from the large set of covariates those that should be include in the model, an iterative stepwise selection procedure based on statistical significance was used to accept or reject a new predictor (variable) as is descripted below:

- At the first iteration, the model is developed using only the AADT or the AADT and the length of the segment for intersections and roadway segment respectively. The $\mathrm{P}$-value for the test statistic is also computed.

- Next, a new predictor is added (the number of obstacles) to the model and, a new model and its $\mathrm{P}$-value is calculated.

- The deviance (the difference in the deviance of the two models) is calculated. If the deviance is less than the fixed threshold value of 0.05 the corresponding effect is kept in the model. Otherwise, the new variable is removed from the model. Once an effect is entered in the model, it is never removed from the model.

- The second and the third steps are applied again for all of the arguments taking into account.

A total of 97 and 87 accidents for roadway segments and intersections were used to generate the models taken from the years 2012, 2014 and 2016. The validation of the models is made with the accident data reported for 2015 (different from those used in the estimation of SPFs). The goodness-of-fit was determined by Mean Absolute Deviance (MAD),
Mean Square Prediction Error (MSPE) and Freeman-Tukey R-square (R2FT). A high value of R2FT indicates a better model. On the other hand, low values of MAD and MSPE indicate a better fit of the model with the actual data.

$$
\mathrm{R}_{\mathrm{FT}}^{2}=1-\frac{\sum \hat{\mathrm{e}}_{\mathrm{i}}^{2}}{\sum\left(\mathrm{f}_{\mathrm{i}}-\overline{\mathrm{f}}\right)^{2}}
$$

Where,

$\hat{e}_{\mathrm{i}}=$ residuals (from the observed and pre-

dicted crashes),

$\bar{f}=\quad$ average of $f_{\mathrm{i}}$ for the sites considered (to account for observed crashes)

$f_{\mathrm{i}}=\quad$ observed crashes for the sites considered.

The MAD and MSPE are estimated as:

$$
\begin{aligned}
& M A D=\frac{1}{n} \sum\left|y_{i}-\mu_{i}\right| \\
& M S P E=\frac{1}{n} \sum\left(y_{i}-\mu_{i}\right)^{2}
\end{aligned}
$$

Where,

$n=\quad$ sample size of segments in the perdition

dataset.

$y_{\mathrm{i}}=\quad$ observed crash frequency for segment

$\mu_{\mathrm{i}}=\quad$ predicted crash frequency for segment

\section{E. Calibration Factors and SPFs developed on Roadway Segments}

The variables considered to estimate the SPFs of this study can be observed in Table 3 for roadway segments. In the case, the volumes used correspond to both directions and therefore, the SPFs will predict the average crashes in of both directions [22]. The statistical parameters of the data set used in the analysis are presented in Table 4 and the SPFs are presented in Table 5 for all cases. Where $K$ is the overdispersion parameter of the SPFs and $C$ is the calibration factor when using the SPFs from [5]. The SPFs used [5] for comparison purposed are showed in Table 6 and Table 7 for multiple (Multiple-Vehicle Nondriveway Collisions, Eq. 12-10 and Table 12-3 [5]) and single (Eq. 12-13 and Table 12-5 [5]) vehicle collision respectively (Four-lane divided arterials and count total crashes).

Table 5 is showed the case of single-vehicle collision without the presence of stations, were the number of expected accidents is constant, wherefore, the variables studied do not present a clear statistical link 
with the frequency of crashes. When the model combines the multiple-vehicles and single-vehicle collision data, the generated equations are dependent on both the typical parameters (AADT and L) and other conditions bases of the corridor (Nsalidas, Sempeat). It is also evident from Table 4 that in some cases, such as the multiple-vehicle collision when both the sections with and without stations are combined, the SPF model obtains a more reliable estimation $(\mathrm{P}$-value $=$ 0.003).

From Table 5 it is clear that variables such as number routes that arrive at the station, the demand of passengers (or number of income to the station), the number of vehicular crossings and Number of vehicular accesses of the section of secondary roads do not present a representative relationship with the number of accidents.
Table 3. Variables Considered to generate SPFs For ROADWAY SEgments

\begin{tabular}{|c|c|}
\hline Variable & Name \\
\hline Average annual daily traffic volume ( BRT) & $A A D T_{B R T}$ \\
\hline $\begin{array}{c}\text { Average annual daily traffic volume } \\
\text { (BRT) vehicles in the mixed lane }\end{array}$ & $A A D T_{M I X}$ \\
\hline Length of roadway segment & $L$ \\
\hline Number traffic lanes to be crossed by a pedestrian & $P_{\text {peat }}$ \\
\hline Number Routes that arrive at the station & $S_{\text {tronca }}$ \\
\hline Bus station length & $L_{\text {estac }}$ \\
\hline Demand of passengers (or number of income to the station) & Demanda \\
\hline Number departures from the station & $N_{\text {Salidas }}$ \\
\hline $\begin{array}{c}\text { Number of vehicular accesses of } \\
\text { the section of secondary roads }\end{array}$ & Acc \\
\hline Number obstacles & obst \\
\hline Number traffic lights Vehicular & Sem $m_{\text {Veh }}$ \\
\hline Entry or exit Buses to the roadway segments & inter \\
\hline Median Width & Sep \\
\hline
\end{tabular}

Source: Authors.

Table 4. Summary of the inPut data For estimation of SPFs on RoAdway SEgments

\begin{tabular}{|c|c|c|c|c|c|c|c|c|c|}
\hline Type of accident & BRT stop-station & Model & $\begin{array}{c}\text { Total } \\
\text { places }\end{array}$ & $\begin{array}{l}\text { Number of } \\
\text { accidents }\end{array}$ & Average & Variance & $\mathrm{K}$ & P-value & $\mathrm{C}$ \\
\hline \multicolumn{10}{|c|}{ Analysis using the SPFs established in the HSM } \\
\hline Multiple-vehicle & N/A & Lineal & N/A & N/A & N/A & N/A & 1.32 & N/A & 1.99 \\
\hline Single-vehicle & N/A & Lineal & N/A & N/A & N/A & N/A & 0.86 & N/A & 12.9 \\
\hline \multicolumn{10}{|c|}{ Analysis using the developed SPFs for local crashes data } \\
\hline \multirow{3}{*}{ Multiple-vehicle } & Presence & Lineal & 45 & 8 & 0.1778 & 0.1949 & 0.180 & 0.041 & N/A \\
\hline & absence & Lineal & 45 & 9 & 0.1875 & 0.1981 & 0.110 & 0.304 & N/A \\
\hline & Presence/ absence & Lineal & 93 & 17 & 0.1828 & 0.1945 & 0.180 & 0.003 & N/A \\
\hline \multirow{3}{*}{ Single-vehicle } & Presence & Constant & 45 & 32 & 0.7111 & 1.0737 & 0.357 & 0.377 & N/A \\
\hline & absence & Constant & 48 & 32 & 0.6667 & 0.5248 & 0.667 & 0.056 & N/A \\
\hline & Presence/ absence & Constant & 93 & 64 & 0.6882 & 0.7821 & 0.125 & 0.099 & N/A \\
\hline \multirow{3}{*}{$\begin{array}{c}\text { Total } \\
\text { (No pedestrians or Bikes) }\end{array}$} & Presence & Constant & 45 & 40 & 0.8889 & 1.1465 & 0.100 & 0.096 & N/A \\
\hline & absence & Lineal & 45 & 41 & 0.8542 & 0.6804 & 0.854 & 0.183 & N/A \\
\hline & Presence/ absence & Constant & 93 & 81 & 0.8710 & 0.8962 & 0.870 & 0.072 & N/A \\
\hline
\end{tabular}

Source: Authors.

Table 5. Developed SPFs for the exclusive lane on roadway segments of the BRT.

\begin{tabular}{|c|c|c|c|c|c|c|c|c|c|c|c|}
\hline \multirow{2}{*}{$\begin{array}{l}\text { Type of } \\
\text { accident }\end{array}$} & \multirow{2}{*}{$\begin{array}{c}\text { BRT } \\
\text { stop- } \\
\text { station }\end{array}$} & \multirow{2}{*}{$\begin{array}{c}\begin{array}{c}\text { Equation } \\
\text { Model }\end{array} \\
\text { Constant }\end{array}$} & \multicolumn{9}{|c|}{$\begin{aligned} N_{\mathrm{spf}}=\exp \left(\hat{\mathrm{a}}+\hat{\mathrm{b}} \times \ln \left(A A D T_{\mathrm{BRT}}\right)+\right. & \hat{\mathrm{c}} \times \ln \left(A A D T_{\mathrm{MIX}}\right)+\hat{\mathrm{a}} \times \mathrm{L}+\hat{\mathrm{e}} \times L_{\text {estac }}+\mathrm{f}^{\hat{\imath}} \times N_{\text {salidas }}+\hat{\mathrm{g}} \times \text { Inter }+\hat{\mathrm{h}} \\
& \left.\times S e m_{\text {peat }}+\hat{\mathrm{k}} \times \text { Obst }+\hat{\mathrm{m}} \times S e p\right)\end{aligned}$} \\
\hline & & & $\ln \left(A A D T_{B R T}\right)$ & $\ln \left(A A D T_{M I X}\right)$ & $L$ & $L_{e s t a c}$ & $N_{\text {salidas }}$ & Inter & $\operatorname{Sem}_{\text {peat }}$ & Obst & Sep \\
\hline \multirow{3}{*}{$\begin{array}{l}\text { Multiple- } \\
\text { vehicle }\end{array}$} & Presence & -23.021 & -3.265 & 4.470 & 8.385 & - & - & - & 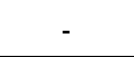 & - & - \\
\hline & absence & -18.617 & 1.916 & - & - & - & - & - & - & - & - \\
\hline & $\begin{array}{c}\text { Presence/ } \\
\text { absence }\end{array}$ & -22.108 & 2.098 & - & 9.487 & 2.962 & -1.671 & 2.627 & - & - & - \\
\hline \multirow{3}{*}{$\begin{array}{l}\text { Single- } \\
\text { Vehicule }\end{array}$} & Presence & -3.401 & 2.559 & -1.692 & 4.481 & - & -0.985 & 2.750 & -0.833 & - & - \\
\hline & absence & -0.405 & - & - & - & - & - & - & - & - & - \\
\hline & $\begin{array}{l}\text { Presence/ } \\
\text { absence }\end{array}$ & -0.441 & - & - & - & - & - & 0.728 & - & - & - \\
\hline \multirow{3}{*}{$\begin{array}{c}\text { Total } \\
\text { (No } \\
\text { pedestrians } \\
\text { or Bikes) }\end{array}$} & Presence & -0.595 & 0.127 & 0.146 & -23.258 & 30.287 & -1.189 & 2.475 & -1.331 & 1.100 & \\
\hline & absence & 4.354 & 0.861 & -1.276 & 3.702 & - & - & 1.470 & -0.369 & - & 0.117 \\
\hline & $\begin{array}{c}\text { Presence/ } \\
\text { absence }\end{array}$ & -0.005 & 0.407 & -0.581 & 4.160 & 14.579 & -0.738 & 1.411 & -0.117 & 0.031 & 0.108 \\
\hline
\end{tabular}

$\hat{\mathrm{a}}, \hat{b}, \hat{c}, \hat{a}, \hat{e}, \hat{f}, \hat{\mathrm{g}}, \hat{h}, \hat{k}$ and $\hat{m}$ are the values in the columns. -: statistically insignificant variable at 95 th percentile confidence level removed. 
Table 5 is depicted that the coefficient that accompanies the average daily volume of BRTs is positive in most cases for sections that have a stations and when all the sections are combined in the case of multiplevehicles collision, which is to be expected considering that the probability of an accident increases as number of vehicles grow up (as was recently presented [30]). The calibration factors (Table 4) are showed that the SPFs [5] underestimate the number of accidents. In the case of single-vehicle accidents, it can be seen that the model does not consider the occupants fall $(\mathrm{C}=12.9)$ for the specific case of this mode of transport and similar high values have been reported in other roadway segments cases $(\mathrm{C}=3.59,[15])$.

The validation of the SPFs developed for the Bogotá BRT and the model calibrated using the SPFs [5] are presented Table 6. Accidents reported in 2015 were used for this purpose, it is important to note that this data was not used previously for the estimation/calibration of SPFs.

Table 6 shows the goodness-of-fit measures in each case, demonstrating that the quality of the adjustment is reduced when SPFs are developed involving both type of accidents, i.e. multiple- vehicle and singlevehicle collisions (MAD and MSPE values are higher compared to values for SPFs developed for each case independently). The values that represent the best fit for each category (multiple-vehicles, a single-vehicle and total) appear shaded in the table, indicating that the most accurate estimates are achieved in general, when there is not bus stop-station in the segment. It is revealing the complexity that involves the presence of bus-stop in the roadway segment. In all the cases, the better fit is achieved when using the developed SPFs for the Bogotá accident data instead the calibrated model of established SPF [5].

\section{F. Calibration Factors and SPFs developed for intersections}

In this case, twelve variables were taken into account that are described in Table 7. The statistical parameters of the data used in the analysis of the intersections are consolidated in Table 8 and the estimated SPFs are shown in Table 9 for the different cases studied (multiple-vehicle, single-vehicle and total). The SPFs [5] used for comparison purposed are showed in Table 8 and Table 9 for multiple (Multiple-Vehicle Collisions, Eq. 12-21 and Table 12-10 [5]) and single (Eq. 12-24 and Table 12-12 [5]) vehicle collision respectively (Signalized three-leg intersections - (8a) and (9a) and, Signalized four-leg intersection - (8b) and (9b) and, count total crashes). These equations are the typical specification for a negative binomial model of intersection collisions [31] [14].

Table 7. Variables Considered to Develop the SPFs FOR INTERSECTION

\begin{tabular}{|c|c|}
\hline Variable & Nombre \\
\hline Annual average daily traffic volume of BRT & $A A D T_{B R T}$ \\
\hline $\begin{array}{c}\text { Annual average daily traffic volume of vehicle } \\
\text { on mixed lane parallel to the BRT lines }\end{array}$ & $A A D T_{M I X}$ \\
\hline $\begin{array}{c}\text { Annual average daily traffic volume of street } \\
\text { that intercepts the intersection }\end{array}$ & $A A D T_{S E C}$ \\
\hline Intersection type & $T_{I N T}$ \\
\hline Median width & $S$ \\
\hline Number traffic lanes to be crossed by a pedestrian & $L_{c r u z}$ \\
\hline Number of accesses with exclusive left-turn lane & $A G_{I Z Q}$ \\
\hline Type of left-turn signal phasing & $F_{i z q}$ \\
\hline Number lanes exclusive right turn & $A G_{D E R}$ \\
\hline $\begin{array}{c}\text { Number of approaches with } \\
\text { right-turn-on-red operation prohibited }\end{array}$ & $A R_{P R O H}$ \\
\hline $\begin{array}{c}\text { Presence of schools within 300 meters } \\
\text { (1000 feet) of the intersection }\end{array}$ & $N_{E S C}$ \\
\hline $\begin{array}{c}\text { Number of alcohol sales establishments within } \\
\text { 300 meters (1000 feet) of the intersection }\end{array}$ & $N_{A L C O H}$ \\
\hline
\end{tabular}

Source: Authors.

The results on Table 9 show for the different cases analyzed, the number of expected accidents depends on at least 4 variables. Variables such as the number of accesses with exclusive left-turn lane, type of leftturn signal phasing, number of lanes exclusive right turn, number of approaches with right-turn-on-red operation prohibited, and the number of alcohol sales establishments within 300 meters of the intersection did not show a clear statistical relationship with the frequency of accidents. The predicted collisions of multiple vehicles using the SPFs of the HSM is outlying

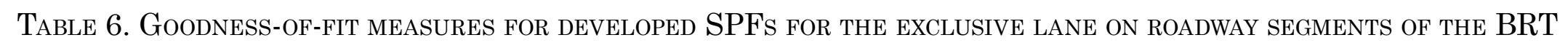

\begin{tabular}{|c|c|c|c|c|c|c|c|}
\hline \multirow{2}{*}{ Type of accident } & & \multicolumn{3}{|c|}{ SPFs of the HSM } & \multicolumn{3}{|c|}{ Specific SPFs BRT Bogotá } \\
\hline & BRT stop-station & MAD & MSPE & $\mathrm{R}_{\mathrm{FT}}^{2}$ & MAD & MSPE & $\mathrm{R}_{\mathrm{FT}}^{2}$ \\
\hline \multirow{3}{*}{ Multiple-vehicle } & Presence & \multirow{3}{*}{0.2873} & \multirow{3}{*}{0.1249} & \multirow{3}{*}{-0.1110} & 0.2842 & 0.1922 & -0.6628 \\
\hline & absence & & & & 0.2814 & 0.1195 & -0.0924 \\
\hline & Presence/ absence & & & & 0.2838 & 0.2012 & -0.7899 \\
\hline \multirow{3}{*}{ Single-Vehicule } & Presence & \multirow{3}{*}{0.7557} & \multirow{3}{*}{0.8058} & \multirow{3}{*}{-0.0938} & 0.6741 & 0.9018 & -0.0151 \\
\hline & absence & & & & 0.6663 & 0.5689 & -0.0114 \\
\hline & Presence/ absence & & & & 0.6997 & 0.6733 & 0.081 \\
\hline \multirow{3}{*}{ Total (No pedestrians or Bikes) } & Presence & \multirow{3}{*}{ N/A } & \multirow{3}{*}{ N/A } & \multirow{3}{*}{ N/A } & 0.8403 & 1.1909 & 0.0076 \\
\hline & absence & & & & 0.8986 & 1.2079 & -0.9823 \\
\hline & Presence/ absence & & & & 0.7084 & 0.7539 & 0.1615 \\
\hline
\end{tabular}


TABLE 8. Summary of the INPUT Data For Estimation of SPFs on INTERSECTIONS

\begin{tabular}{|c|c|c|c|c|c|c|c|c|}
\hline Type of accident & Model & Total places & Number of accidents & Average & Variance & K & P-value & C \\
\hline \multicolumn{7}{|c|}{ Analysis using the SPFs established in the HSM } \\
\hline Multiple-Vehicle & Lineal & N/A & N/A & N/A & N/A & $0.33-0.39$ & N/A & 0.0788 \\
\hline Single-Vehicule & Lineal & N/A & N/A & N/A & N/A & 0.36 & N/A & 0.1044 \\
\hline \multicolumn{7}{|c|}{ Analysis using the developed SPFs for local crashes data } \\
\hline Multiple-Vehicle & Lineal & 87 & 39 & 0.4483 & 0.7618 & 0.568 & 0.019 & N/A \\
\hline Single-Vehicule & Lineal & 87 & 6 & 0.0690 & 0.0650 & 0.069 & 0.118 & N/A \\
\hline Total (No pedestrians or Bikes) & Lineal & 87 & 45 & 0.5172 & 0.8573 & 0.501 & 0.032 & N/A \\
\hline
\end{tabular}

Source: Authors.

Table 9. Developed SPFs for the intersections of the EXClusive LANe of the BRT

\begin{tabular}{|c|c|c|c|c|c|c|c|c|}
\hline \multirow{2}{*}{ Type of accident } & \multirow{2}{*}{$\begin{array}{c}\begin{array}{c}\text { Equation } \\
\text { Model }\end{array} \\
\text { Constant }\end{array}$} & \multicolumn{7}{|c|}{$N_{s p f}=\exp \left(\hat{\mathrm{a}}+\mathrm{b} \times \ln \left(A A D T_{B R T}\right)+\hat{\mathrm{c}} \times \ln \left(A A D T_{M I X}\right)+\hat{\mathrm{d}} \times \ln \left(A A D T_{S E C}\right)+\hat{\mathrm{e}} \times T_{I N T}+\mathrm{f} \times L_{C R U Z}+\hat{\mathrm{g}} \times N_{E S C}+\hat{\mathrm{h}} \times \mathrm{S}\right)$} \\
\hline & & $\ln \left(A A D T_{B R T}\right)$ & $\ln \left(A A D T_{M I X}\right)$ & $\ln \left(A A D T_{S E C}\right)$ & $T_{I N T}$ & $L_{C R U Z}$ & $N_{E S C}$ & $S$ \\
\hline $\begin{array}{l}\text { Multiple- } \\
\text { Vehicle }\end{array}$ & -18.564 & -1.390 & 1.865 & 0.900 & - & 0.127 & 0.351 & - \\
\hline $\begin{array}{l}\text { Single- } \\
\text { Vehicule }\end{array}$ & -9.484 & -0.664 & - & 0.584 & -1.973 & 2.119 & - & 0.186 \\
\hline $\begin{array}{c}\text { Total } \\
\text { (No pedestrians } \\
\text { or Bikes) }\end{array}$ & -16.613 & -1.031 & 1.494 & 0.833 & -0.195 & 0.253 & - & 0.005 \\
\hline
\end{tabular}

$\hat{\mathrm{a}}, \mathrm{b}, \hat{c}, \hat{\mathrm{d}}, \hat{\mathrm{e}}, \hat{\mathrm{f}}, \hat{\mathrm{g}}$ and $\hat{\mathrm{h}}$ are the values in the columns. -: statistically insignificant variable at 95th percentile confidence level removed.

Source: Authors

TABle 10. Goodness-of-Fit Measures For DeVEloped SPFs For the InTERsections of THE EXCLUSIVE LANE OF THE BRT

\begin{tabular}{|c|c|c|c|c|c|c|}
\hline \multirow{2}{*}{ Categoría } & \multicolumn{3}{|c|}{ SPFs of the HSM } & \multicolumn{3}{c|}{ Specific SPFs BRT Bogotá } \\
\cline { 2 - 7 } & MAD & MSPE & $\mathrm{R}_{\mathrm{FT}}^{2}$ & MAD & MSPE & $\mathrm{R}_{\mathrm{FT}}^{2}$ \\
\hline Multiple-vehicle & 0.7425 & 1.2740 & -0.0322 & 0.6830 & 1.119 & 0.0934 \\
\hline Single-Vehicule & 0.2431 & 0.2900 & -0.0335 & 0.2262 & 0.2829 & -0.008 \\
\hline Total (No pedestrians or Bikes) & N/A & N/A & N/A & 0.8136 & 1.7573 & -0.0054 \\
\hline
\end{tabular}

Source: Authors.

(calibration factor $\mathrm{C}=0.0788$ ) which is attributed to the segregation of the BRT from the mixed traffic because it is under the reported-literature values [16]. In addition, the table indicates that the most common accidents at the intersection is multiple-vehicles collision (39 accidents).

The coefficients of the Annual Average Daily Traffic Volume of Street that intercepts the intersection $\left(\mathrm{AADT}_{\mathrm{SEC}}\right)$ of the equations presented in Table 9 are positive as is expected, since a greater number of mixed vehicles that cross the exclusive BRT line at the intersection can derivative a greater frequency of accidents (generally, AADT was reported statistically significant in most of the intersection crash prediction models [27] - [32]). Also, the maximum number of Traffic Lines Crossed by a pedestrian in any maneuver $\left(L_{\text {cruz }}\right)$ are positive indicating an increase in the hazard index. Under this same philosophy, the coef- ficients that accompany the width of the separator $(S)$ is positive, indicating an increase in the level of risk.

On the other hand, the calibration factors ( $\mathrm{C}$ in Table 8) show that the SPFs [5] overestimate the number of accidents (contrary to the case of the roadway sections, $\mathrm{C}<1.0)$.

The validation of the SPFs developed for the Bogotá BRT and the model calibrated using the SPFs [5] of the intersections are presented in Table 10. In a similar way, the accidents reported in 2015 were used for this purpose. Table 10 shows the goodness-of-fit in each case. The results is showed that, in the case of multiple-vehicle collision, the best fit occurs when using the SPFs developed (MAD and MSPE values are less than the values for the SPFs [5] and the R2FT value is higher) [14]. For single-vehicle collision, the goodness-of-fit measures using both kind of SPFs are similar. 


\section{Conclusions AND RECOMMENDATIONS}

Analysis of the accident dataset provided by the Bogota's Secretary of Mobility allowed to identify that the corridor of Caracas Avenue has the highest number of crashes (456 in total), and thus, the general accident prediction model [5] for Urban and Suburban Arterial was applied in this corridor. For this, the base geometric and traffic operation conditions of the "Caracas" corridor in all its extension and a part of the corridor "Caracas Sur-Usme" (between 6th and 11 South streets) were determined and also, the accident modification factors, the accident and traffic volume records provided by the Bogota's Secretary of Mobility. The safety performance functions [5] were calibrated to the local conditions and, alternatively, a set of the specific functions for the Bogota's BRT were developed using a negative binomial model.

The development of SPFs for exclusive BRT lines are showed that, in general, the equations depend of the typical variables established [5] that are the annual average daily traffic volume and length of segment on roadway segment or the annual average daily traffic volume at intersections. Variables such as number of routes that arrive at the station, the demand of passengers (or number of income to the station), the number of vehicular crossings and Number of vehicular accesses of the section of secondary roads do not present a representative relationship with the frequency of accidents on roadway segments. Additionally, the number of accesses with exclusive left-turn lane, type of left-turn signal phasing, number of lanes exclusive right turn, number of approaches with right-turn-onred operation prohibited, and the number of alcohol sales establishments did not show a clear statistical relationship with the number of crashes at intersections. As a special case, the SPF for single-vehicle collision is constant and thereby, it does not connection with any variable included in this study.

The calibration factors of established SPFs [5] are shown that the SPFs underestimate the number of accidents on roadway segments. In the case of singlevehicle accidents, it can be seen that the model does not consider the occupants fall $(\mathrm{C}=12.9)$ for the specific case of this mode of transport. By contrast, the calibration factors show that the SPFs [5] overestimate the number of accidents at interception ( $\mathrm{C}$ value between 0.0788 and 0.1044 ).

The validation of the developed SPFs and the SPFs [5] use three goodness-of-fit measures is exposed that the better fit is achieved when using the developed SPFs for the Bogota accident data instead the calibrated model of established SPF [5]. Also, the estimated SPF model on roadway segments for multiple-vehicle collision with presence and absence of bus-stop-station has the most reliable estimation $(\mathrm{P}$-value $=0.003$.
This study is a first step towards the consolidation of SPFs to apply to BRTs that are installed on the central-line of main roads of the city and use an exclusive lane system of all other transport systems (public or private) or mobility (bicycle paths). It is limited to the amount of data available both for accident and operation and / or geometry of the corridor. To give continuity to this study it is recommended evaluates other corridors different to "Caracas Avenue".

\section{ACKNowledgments}

This research was developed at the Colombian School of Engineering "Julio Garavito". Any opinions, findings and conclusions or recommendations expressed in this study are those of the writers and do not necessarily reflect the views of the Colombian School of Engineering "Julio Garavito". The experimental data used in this work was obtained from the Bogota's Secretaria de Movilidad and Transmilenio S.A.

\section{REFERENCES}

[1] M. Peden, G. Sharma and K. McGee, "Road traffic injuries," in The injury chart book: a graphical overview of the global burden of injuries, Geneva, Switzerland: World Health Organization, 2002, ch. 2, pp. 19-27.

[2] M. Peden, R. Scurfield, D. Sleet, D. Mohan and A. Hyder, World Report on Road Traffic Injury Prevention, Geneva, Switzerland: World Health Organization, 2004.

[3] A. D. Lopez, C. D. Mathers, M. Ezzati, D. T. Jamison and C. J. Murray, "Global and regional burden of disease and risk factors, 2001: systematic analysis of population health data," The Lancet, vol. 367, no. 9524, pp. 1747-1757, May. 2006. https://doi.org/10.1016/S0140-6736(06)68770-9

[4] A. M. Novoa, K. Pérez \& C. Borrell, "Efectividad de las intervenciones de seguridad vial basadas en la evidencia: una revisión de la literatura," Gac. Sanit., vol. 23, no. 6, pp. 553.e1-553.e14, Nov.-Dec. 2009. https://doi.org/10.1016/j. gaceta.2009.04.006

[5] AASHTO, Highway Safety Manual (Vol. 1). Washington, DC., USA: American Association of State Highway and Transportation Officials, 2010.

[6] C. Mattar-Habib, A. Polus and H. Farah, "Further evaluation of the relationship between enhanced consistency model and safety of two-lane rural roads in Israel and Germany," EJTIR, vol. 4, no. 8, pp. 320-332, Dec. 2008. https://doi.org/10.18757/ejtir.2008.8.4.3360

[7] A. S. Hakkert and V. Gitelman, "Thinking about the history of road safety research: Past achievements and future challenges," Transp. Res F-Traf., vol. 25, Part. B, pp. 137149, Jul. 2014. https://doi.org/10.1016/j.trf.2014.02.005

[8] W. Hook, "Institutional and regulatory options for bus rapid transit in developing countries: Lessons from international experience," Transp. Res. Rec., vol. 1939, no. 1, pp. 184-191, Jan. 2005. https://doi.org/10.1177/0361198105193900121

[9] N. Duduta, C. Adriazola, D. Hidalgo, L. A. Lindau and R. Jaffe, "Understanding road safety impact of high-performance bus rapid transit and busway design features," Transp. Res. Rec., vol. 2317, no. 1, pp. 8-14, Jan. 2012. https://doi.org/10.3141/2317-02

[10] K. C. Keong-Goh, G. Currie, M. Sarvi and D. L. Goh, "Road safety benefits from bus priority: an empirical study," Transp. Res. Rec., vol. 2352, no. 1, pp. 41-49, Jan. 2013. https://doi.org/10.3141/2352-05 
[11] Manual de auditorías de seguridad vial: estrategias para contribuir a la disminución de los indices de accidentalidad vial en la ciudad de Bogotá, D.C., 1rd ed., Alcaldía Mayor de Bogotá D.C., Bogotá, D.C., Colombia, 2005.

[12] S. Yoon, S.-Y. Kho and D.-K. Kim, "Effect of regional characteristics on injury severity in local bus crashes: use of hierarchical ordered model," Transp. res. rec., vol. 2647, no. 1, pp. 1-8, Jan. 2017. https://doi.org/10.3141/2647-01

[13] A. Farid, M. Abdel-Aty and J. Lee, "Comparative analysis of multiple techniques for developing and transferring safety performance functions," Accid. Anal. Prev., vol. 122, no. 1, pp. 85-98, Jan. 2019. https://doi.org/10.1016/j. aap.2018.09.024

[14] A. Northmore and E. Hildebrand, "Aggregated North American Safety Performance Functions for Signalized and Stop-Controlled Intersections," Can. J. Civ. Eng., vol. 46, no. 12, Aug. 2019. https://doi.org/10.1139/cjce-20190161

[15] C. Sun, P. Edara, H. Brown, J. Berry, B. Claros, and X. Yu, "Missouri Highway Safety Manual Recalibration," Dept. Civ. Environ. Eng., MU, Columbia, Missouri, USA, Tech. Rep. cmr 18-001, Feb. 2018.

[16] R. Karmacharya, "Estimating calibration factors and developing calibration functions for the prediction of crashes at urban intersections in Kansas," M.S. thesis, Dept. CE, Coll. Eng, KSU, Manhattan, Kansas, USA, 2019. [Online]. Available: http://hdl.handle.net/2097/39444

[17] J. Cortés, “¿Cuáles son los grandes retos de un sistema de transporte masivo para Bogotá?," bogota.gov.co. [Online]. Available: http://www.bogota.gov.co/article/temas-de-ciu$\mathrm{dad} / \mathrm{movilidad} / \mathrm{cuales}$-son-los-grandes-retos-de-un-sistema-de-transporte-masivo-para-bogota [Accessed Nov. 12, 2018].

[18] D. Hidalgo and L. Gutiérrez, "BRT and BHLS around the world: Explosive growth, large positive impacts and many issues outstanding," Res. Transp. Econ., vol. 39, no. 1, pp. 8-13, Mar. 2013. https://doi.org/10.1016/j.retrec.2012.05.018

[19] F. Gómez and J. P. Bocarejo, "Accident prediction models for bus rapid transit systems: generalized linear models compared with a neural network," Transp. Res. Rec., vol. 2512 , no. 1, pp. 38-45, Jan. 2015. https://doi. org/10.3141/2512-05

[20] J. Santos-Reyes, V. Avalos-Bravo and E. Rodriguez-Rojas, "Accident analysis of a transport system: the case of the bus rapid transit system in Mexico City," in PSAM 12, IAPSAM, Eds., Honolulu, Hawaii, USA, Jun. 22-27, 2014. [Online]. Available: http://meetingsandconferences. com/psam $12 /$

[21] R. Srinivasan, D. Carter and K. Bauer, "Safety performance function decision guide: SPF calibration vs SPF development," UNC, Dept. Transp, Chapel, Hill, USA, Tech. Rep. FHWA-SA-14-004, Sept. 2013.

[22] Safety Analyst. (2009). AASHTO. Aug. 5, 2009. [Online]. Available: http://www.safetyanalyst.org/spf_dev_guidelines/Developing\%20SPFs\%20with\%20State\%20or\%20 Local\%20Highway\%20Agency\%20Data.pdf [Accessed 31 Mar. 2018].

[23] Global BRT Data. (2012). Across Latitudes and CulturesBus Rapid Transit (ALC-BRT) \& Volvo Research and Educational Foundations (VREF), Mar. 31, 2012. [Online]. Available: https://brtdata.org/

[24] K. Rodríguez \& S. Henao, "Aplicación del Modelo de Predicción de accidentes en vías de uso exclusivo de BRT, según el Manual de Seguridad Vial (HSM 2010) de Estados Unidos, Estudio de Caso: Ciudad de Bogotá," in $X X$ CLATPU, ALATPU, Eds., Medellín, Antioquia, Colombia, Jul. 23-26, 2018, pp. 1316-1326. [Online]. Available: http://www.clatpu.org/es/Pages/Ponencias
[25] A. Baamonde-Roca \& I. Pérez-Pérez, "Estimación de accidentes en carreteras convencionales de dos carriles según el Manual de Seguridad Viaria norteamericano," Carreteras, vol. 189, no. 1, pp. 18-27, May-Jun. 2013.

[26] J. Lu, K. Haleem, A. Gan and P. Alluri, "Safety Performance Functions for Florida's Freeways," in T\&DI Congress 2014, A. Varma and G. Gosling, Eds., Orlando, Florida, USA, Jun. 8-11, 2014. pp. 321-331. https://doi. org/10.1061/9780784413586.031

[27] B. Brimley, M. Saito and G. Schultz, "Calibration of Highway Safety Manual Safety Performance Function: Development of New Models for Rural Two-Lane Two-Way Highways," Transp. Res. Rec., vol. 2279, no. 1, pp. 82-89, Jan. 2012. https://doi.org/10.3141/2279-10

[28] J. F. Kraus, C. L. Anderson, S. Arzemanian, M. Salatka, P. Hemyari and G. Sun, "Epidemiological aspects of fatal and severe injury urban freeway crashes," Accid. Anal. Prev., vol. 25, no. 3, pp. 229-239, Jun. 1993. https://doi. org/10.1016/0001-4575(93)90018-R

[29] S. Khan, R. Shanmugam and B. Hoeschen, "Injury, fatal, and property damage accident models for highway corridors," Transp. Res. Rec., vol. 1665, no. 1, pp. 84-92, Jan. 1999. https://doi.org/10.3141/1665-12

[30] J. Hong, R. Tamakloe and D. Park, "A Comprehensive Analysis of Multi-Vehicle Crashes on Expressways: A Double Hurdle Approach," Sustainability, vol. 11, no. 10, pp. 1-22, May. 2019. https://doi.org/10.3390/su11102782

[31] E. Donnell, V. Gayah and L. Li, "Regionalized safety performance functions," Penn State, Dept. Transp, PA, USA, Tech. Rep. FHWA-PA-2016-001-PSU WO 017, Jan. 8, 2016.

[32] K. Wang, S. Zhao and E. Jackson, "Functional forms of the negative binomial models in safety performance functions for rural two-lane intersections," Accid. Anal. Prev., vol. 124, pp. 193-201, Mar. 2019. https://doi.org/10.1016/j. aap.2019.01.015

Kelly Andrea Rodríguez Polo received the M.Sc. degree in engineering, transit and transportation from the Colombian School of Engineering "Julio Garavito", Bogotá, Colombia, 2018. Currenly, she is Ph.D. student in engineering and assistant professor of Military University "Nueva Granada". https://orcid.org/00000002-7907-0305

Santiago Henao Pérez received the M.Sc. degree in engineering, transport engineering and operations from the University of Newcastle-Upon-Tyne, England, in 1980. He is representative of Transport Research Laboratory (TRL) of the United Kingdom in Bogotá, where he has teaching courses in transport engineering and road safety. Currenly, He is professor of the Colombian School of Engineering "Julio Garavito", where he is Director of the Center for Studies of Roads and Transportation. 